Kosztopulosz Andreász - Kuruczleki Éva (szerk.) (2020): Társadalmi és gazdasági

folyamatok elemzésének kérdései a XXI. században. Szegedi Tudományegyetem

Gazdaságtudományi Kar, Szeged, https://doi.org/10.14232/tgfek21sz.2

\title{
A kompozit mutatók és helyettesítő változók problémái
}

\author{
Dusek Tamás
}

\begin{abstract}
Napjaink statisztikai mutatókat felhasználó gazdasági-társadalmi elemzéseinek egyik jellegzetessége a konkrét, kézzelfogható eredeti adatok helyettesitése kevésbé megfogható kompozit indikátorokkal, amik a megfigyelési egységeket rangsorolják vagy valamilyen méröszámmal irják le. Néhány közismert példát megnevezve, oktatási intézmények minöségi rangsorai, világvárosok élhetösége, városok biztonsága, városok okossága, országok innovativitása, kórházi teljesitmény rangsorolása, emberi fejlettség indexe, országok versenyképessége általában sok (ami a néhánytól a sokszázig terjed) változó figyelembe vételével képzett mutatókkal történik. Az ilyen elemzések egy részében ráadásul közvetlenül nem mérhetö, sokszor bizonytalan koncepciókat irnak le, a közvetlen mérhetöség hiányában helyettesitö (proxy) változókkal, amelyek alkalmassága sokszor megkérdőjelezhetö, és amelyek eltávolítják egymástól a koncepciót és az adatot. A tanulmány a kompozit mutatók és helyettesitö változók elterjedésének okaival, következményeivel, problémáival foglalkozik.
\end{abstract}

Kulcsszavak: kompozit mutatók, helyettesitö változók, eredmények értelmezése, okos város mutatók

\section{Bevezetés}

Napjaink statisztikai mutatókat felhasználó gazdasági-társadalmi elemzéseinek egyik jellegzetessége a konkrét, kézzelfogható, természetes mérési egységben kifejezett eredeti adatok helyettesítése kevésbé megfogható kompozit indikátorokkal, amik a megfigyelési egységeket rangsorolják vagy valamilyen mérőszámmal írják le. Az ilyen elemzések egy részében ráadásul közvetlenül nem mérhető, sokszor bizonytalan koncepciókat írnak le, a közvetlen mérhetőség hiányában helyettesítő (proxy) változókkal, amelyek alkalmassága sokszor megkérdőjelezhető, és amelyek eltávolítják egymástól a koncepciót és az adatot. A tanulmány ennek a jelenségnek a hátterét tárgyalja, a kompozit mutatók és helyettesítő változók elterjedésének okait, következményeit, problémáit. Az okok között a mérés fogalmának történelmi átalakulásával foglalkozik előszőr, majd az egyéb intézményi és technológiai körülményekkel. Ez követően a lehetséges veszélyeket illusztráló szemléletes és hosszabb példaként az okos város kompozit mutatók közül tárgyal néhányat, bemutatva azok inadekvát alapmutatóit.

\section{A hagyományos méréstől a proxy változókat tartalmazó kompozit mutatókig}

A mérés alatt, hagyományos hétköznapi jelentése alapján egy olyan müveletet (cselekvést, cselekvéssorozatot) értenek, amelynek során egy objektum valamely kézzelfogható tulajdonságát számszerüen fejezik ki egy elöre meghatározott, valamilyen megegyezésen alapuló skálán. Az ilyen mérésnek az eredménye a mérőszám és a mértékegység; a mérőszám megadja, hogy a mennyiség hányszorosa 
a mértékegységnek. Ezzel találkozik minden kisgyerek a hétköznapi életben, majd az iskolában, kezdetben még kézzelfogható és belátható nagyságrendben (például az emberi test súlyának és magasságának a megmérése), majd ez bővül ki a mikroszkopikus és makroszkopikus nagyságrendekre. Ez a hagyományos jelentés nem módosul, amikor a mérés már bonyolultabb jellemzöre vonatkozik és valamilyen komolyabb technológiai segítségre, mérőeszközre van szükség, mint a hőmérséklet, elektromos áramerősség, hullámhossz, légnyomás, vérnyomás, szemnyomás, vércukorszint mérésekor. Szintén tartalmazza a mérés hagyományos jelentése az olyan értelemben származtatott méréseket, amikor egynél több alapmérés közötti viszony a mérés végeredménye: a sebességhez a megtett útra és időre, a sürüséghez a tömegre és térfogatra van szükség. Ezek, bár származtatott mérések, mégis még kézzelfogható, szemléletes jelenségekre vonatkoznak.

A mért objektum lehet bármi: ember, más élőlény, tárgy, földterület; a tulajdonság szintén bármi, ami értelmesen kapcsolatba hozható az objektummal: súly, magasság, térfogat. Az idő(tartam) szintén mérhető. A mérőskálához tartozik valamilyen mértékegység, mértékegység nélküli mérés hagyományos értelemben nincsen. A magyar mérés szónak megfelelő angol measurement és német Messen főnévnek ugyanez az alapjelentése. A mér ige magát a mérési folyamatot fejezi ki, a különböző igekötős igék pedig pontosítják, árnyalják vagy bővítik az alapjelentését: megmér, lemér, felmér, elmér, kimér, összemér, hozzámér, bemér.

Méréssel elvileg folytonos tulajdonságok nagyságát határozzák meg. A diszkrét nagyságoknál hagyományosan nem használatos a mérés, azokat megszámlálással kapjuk és darabszámban fejezzük ki (vagy annak megfelelően, de máshogyan megnevezve, például ha emberekről van szó emberként, lakosként, föként, népességszámként).

Röviden ez tehát az a hagyományos és hétköznapi jelentése a mérésnek, amely változatlanul érvényes, de emellett a tudományos életben számos többletjelentés jelent meg, amelyek tudományterületenként is különbözőek lehetnek.

\subsection{Mérés, mint sokaságok és sokaságok közötti viszonyok jellemzése különféle méröszámokkal}

$\mathrm{Az}$ első jelentésbővülés még a legegyszerübb statisztikai mutatók készítéséhez kötődik, amikor már nemcsak az egyedek jellemzőit mérték meg, hanem sok egyed együttesét, mai szóval statisztikai sokaságokat jellemeztek különféle, nagyon heterogén mérőszámokkal. Ez a folyamat a demográfiai adatok elemzésével kezdődött a 17. században, és bár akkor még lehet, hogy ezt nem mérésnek nevezték, de manapság teljesen szokásos az átlag, arány, szórás, korreláció stb. kiszámítása helyett azoknak a megméréséről beszélni.

\subsection{Mérés, mint értékbeli aggregátumok képzése}

Aggregátumok képzésekor a mért tulajdonság jellege ugyanaz vagy hasonló, de a mértékegysége különböző (energiafajták mértékegységének átszámítása kőszénegyenértékre, kőolajegyenértékre, megajoulra; állatállomány kifejezése számosállatban; közúti forgalom nagyságának kifejezése egységjármüben - a példák 
érzékeltetik, hogy a közös egységre hozás sokszor nem egyszerüen megoldható és így vitatható), vagy a mértékegység ugyanaz, de a sokaság elemei heterogének (árszínvonal számítása).

\subsection{Mérés, mint közvetlenül nem megfigyelhetö elvontabb koncepciók leírása közvetlenül megfigyelhetö jellemzökkel}

Ez az a változás, amely jelen tanulmány szempontjából a legfontosabb. A jelenségre szakterületenként eltérő szóhasználat honosodott meg: helyettesítő változók, proxy változók, manifeszt változók, indirekt változók, közvetett változók használata. Így például a társadalmi kohézió helyett a bünesetek számának, egyetemek minősége helyett a tanár/diák aránynak, tudományos befolyás helyett a hivatkozások számának, társadalmi státusz helyett a vagyon nagyságának a használatakor helyettesítő változóval van dolgunk, mivel maga a jelenség közvetlenül nem mérhető. Az filozófiai színezetü vita, hogy a direkt (manifeszt) változó határozza-e meg, befolyásolja-e az indirektet (látenst), vagy fordítva, vagy is-is.

Az ilyen változók jellemzően a pszichometria révén jelentkeztek először tömegesen a 20. század elején. Embereken kívül bármely más egység (települések, országok, egyéb embercsoportok, vállalkozások, iskolák, kórházak) jellemzésére is használatosak ilyen mutatók. Az 1970-es évektől jelentőségük annyiban csökkent, hogy ritkábbá váltak az egyetlen helyettesítő változót használó elemzések és elterjedtek az egynél több helyettesítő változót valahogyan kombinálók. Így az utolsó példában, a társadalmi státusznál gyakoribb az egynél több változó használata, vagyis a vagyon mellett például a jövedelem, iskolai végzettség, foglalkozás, lakóhely.

\subsection{Mérés, mint egynél több indikátor összegyúrása kompozit mutatóvá}

Több alapindikátort összegyúró kompozit mutatókat képezhetnek számérték hozzárendelésével (mértékegység többnyire nincs) a vizsgált elemekhez, vagy csak a vizsgált elemek közötti rangsor felállításával. A figyelembe vett szempontok száma legalább kettő, de jellemzően kettőnél több és a néhány tucat közé eső; a szempontok egymástól jellegükben nagyon eltérhetnek. Az ilyen értelmü mérések a 19. század második felében kezdődtek az első hitelminősítésekkel. Két fó ága van abból a szempontból, hogy az alapindikátorok ugyanazt kívánják-e kifejezni, vagy ugyanarra a jelenségre vonatkoznak, de annak némileg eltérő aspektusára. Az első változat a skálaalkotás terepe: standardizált (ezért időben, térben, csoportok között összehasonlítható eredményű) skálák létrehozása, kérdőívből származó eredmények felhasználásával. Ez a pszichometria tárgya, de hasonlóval találkozunk a marketingkutatásban is, de ott a megismételhetőség, standardizálás kevésbé gyakori, inkább a skála egydimenziós volta a fontos (a mért tulajdonságok is más jellegüek; a pszichometriában például hisztéria, szorongás, depresszió, hipochondria, marketingkutatásban a márkahüség, adományozási hajlandóság, termékvásárlási hajlandóság; utóbbiak sokkal szituációfüggőbbek, mint az általánosabb pszichometriai mérések).

A másik változat a kompozit mutatók terepe: ekkor a megismételhetőséget és összehasonlíthatóságot nem tudják vagy nem akarják figyelembe venni; az 
alapindikátorok származhatnak bármilyen forrásból, amely egy komplex indikátoron belül is rendkívül heterogén lehet. Az ilyen mutatók igazán látványos terjedése az 1970-es évekre tehető. Ezek közül csak a települések összehasonlítását célzó mutatókat kiragadva, Feenan és társai 2017-es áttekintése már több mint 300 olyan indexet mutat be, amelyek a világ nagyvárosait hasonlítják össze különböző életminőségi szempontokból. Mérik a városok tehetségét, márkanevét, digitalizáltságát, biztonságát, kockázatát, innovativitását, közlekedését, infrastruktúráját, ingatlanpiacát, társadalmi integráltságát, munkaerőpiacát. És ez csak a világvárosokra vonatkozó részlet, ezen túlmenően külön világrészekre, országokra, országrészekre is rendszeresen közölnek újabb és újabb indexeket.

\subsection{Mérés, mint bármely tulajdonság hozzárendelése valamely megfigyelési egységhez}

Végül a mérés előző jelentésváltozásaihoz képest eltérő jellegü jelentésváltozás is megfigyelhető. Ez a statisztika tankönyvek elterjedt mérés meghatározása: „A mérés számok meghatározott szabályok szerinti hozzárendelése jelenségekhez (dolgokhoz, tárgyakhoz, eseményekhez), illetve ezek bizonyos tulajdonságaihoz." (Korpás 1996, 11. o.) Ezt követően viszont a mérési szintek tankönyvi ismertetéséből kiderül, hogy az is mérés, ha egy autóról megmondjuk annak rendszámát, típusát, színét, vagyis olyan jellemzőket, amelyeket vagy kódolás, vagy osztályba sorolás kapcsán emlegetünk. A tankönyvek többségébe bekerült és így most már hagyományosnak tekinthető Stevens-féle mérési skálák a skálák matematikai tulajdonságainak a megkülönböztetésén alapulnak. Sokszor tévesen alkalmazzák ezt a koncepciót mérőszámokra, aggregátumokra, kompozit mutatószámokra is (a mérés első, második és negyedik pontban bemutatott jelentésbővüléseire). A megelöző pontoknál ugyanakkor annyiban szélesebb ez a mérés értelmezés, hogy tartalmazza az elemek kódolását, osztályozását, rangsorolását is, amelyeknél a számoknak nincs mennyiségi jelentése, csak címkeadó, megkülönböztető vagy rangsoroló szerepe.

\section{A kompozit mutatók terjedésének motiváció}

A kompozit mutatók elterjedését számos tényező támogatta és támogatja. Először, a kompozit indikátorok és azok alkotóelemei a közszféra nagy projektjeiben általában értékelő, felmérő, auditáló, monitoringot segítő szerepet játszanak. Mindezt teszik többnyire óriási adminisztrációs költségek mellett, főként proxy változókat használva. A közösségi finanszírozású projektek tipikus sikerindikátorai úgy néznek ki, hogy ez és ez volt az n-1-ik periódusban (a projekt előtt), majd ez az n+1-ik periódusban (a projekt után). Az előtt és után az időnek egy szűk metszetét jelenti, vagyis a hosszú távú hatások felmérése és az autonóm folyamatok és a projekt okozta folyamatok elkülöníthetősége jellemzően problémás vagy nem vizsgált.

Másodszor, a kompozit indikátorok készítése óriási publikációs piacot nyitott meg, mind az akadémiai szférában, mind a tömegtájékoztatás számára jól eladható hangzatos címkék révén. Egy kompozit mutatót tartalmazó publikáció, a tömegmédiában látványos infografikákkal megtámogatva, sokkal könnyebben publikálható, mint egy igényes verbális elemzés, amely egy komplex kérdéskör 
szövevényes összefüggéseit próbálja meg feltárni. A tömegmédiában kompozit mutatókat használnak fel témák köztudatba dobására, érzékenyítésre, amely szándékot maguk a mutatókészítők is sokszor deklarálnak. Az ENSZ Fejlesztési Programja által publikált Emberi Fejlettség Indexe (HDI) 2018-as kiadványában így írnak erről: „Az országok HDI alapján történő rangsorolása átalakította a fejlettségi diskurzust és megfosztotta trónjától az egy főre jutó jövedelmet, mint a fejlettség egyedüli mutatóját" (UNDP 2018, 1. o.)

Harmadszor, mélyen gyökerező meggyőződés, hogy a több adat jobb, mint a kevesebb, a kompozit indikátor sokváltozós elemzésként tudományosabb, mint az egy szempontot leíró adat. Ez igaz is volt arra az időszakra, amikor alig-alig volt egyáltalán bármiféle adat, de a jelen adatbőségben és adatredundanciáiban inkább az adatszelekció problémáival kell megküzdeni. A több adatnál fontosabbak az adatok minőségével kapcsolatos szempontok, mint a megismételhetőség, érvényesség, pontosság, konzisztencia, felhasználhatóság, és az okos város mutatókkal kapcsolatban különösen érdekes a relevancia és a jelenséggel való kapcsolat kérdése. Az adatok mennyiségéhez kötődő további tévhit, miszerint egy kompozit indikátor többet mond a vizsgált jelenségről, mint a kompozit indikátort összetevő alapindikátorok. Ez a kijelentés nincs alátámasztva, az viszont látható, hogy a kézzelfogható tartalommal bíró alapindikátorok helyett a valóságtól eltávolított skálájú értékeket kapunk, amelynek adekvát értékeléséhez rendre vissza kellene térni az alapindikátorok értékeihez. Ez legegyszerübben szemléletes példákkal mutatható be. Egy korai (a 19. század közepén javasolta Adolphe Quetelet) kompozit indikátor a testtömegindex, amely a testtömegnek és a testmagaság négyzetének a hányadosa (szokásos mértékegysége a furcsának tünő kilogramm/négyzetméter, ami többnyire lemarad értékének megadásakor). Ha valakiröl annyit tudunk, hogy 25 a testtömegindexe, akkor lehet 154 centi magas és 60 kilós vagy 180 centi magas és 82 kilós vagy 200 centi magas és 100 kilós. Lényeges alapinformációkat vesztettünk el, cserébe valamilyen másodlagos jelentőségü mérőszámért. Még rosszabb a helyzet az Emberi Fejlettség Indexével (HDI), amely eltünteti a sokkal lényegesebb felhasznált alapmutatókat (az iskolázottságra, várható élettartamra, gazdasági teljesítményre vonatkozóan), és egy olyan skálát eredményez, amelyen (egy példa a furcsaságokra) Szlovákia 2017-ben Katar és Brunei közé kerül nagyjából ugyanolyan értékkel a mértékegység nélküli skálán. (UNDP 2018) Az adatsürítés nem jó minőségü többletinformációt hozott létre, hanem megtévesztő és rossz új információt, amely azon az implicit feltevésen alapul, hogy az emberek egészsége, oktatása és jövedelme ugyanazt a minőséget képviseli és egymással problémamentesen felcserélhetők. A példánál tudjuk, hogy Katarnál és Bruneinél az olajjövedelmek magas volta (Szlovákiához képest) kompenzálja az oktatásban vagy az egészségügyben lévő alacsonyabb szintjüket, így kerül a három ország azonos „emberi fejlettség” szintre. Az eltérő minőséget képviselő indikátorok problémája némileg kezelhető azon országpároknál, ahol mindegyik indikátornál ugyanolyan előjelü a különbség, mert itt a sorrend legalább megállapítható. A sorrendinél magasabb szintü skálán ugyanakkor ezekben az esetekben sem fejezhetö ki a különbség.

Negyedszer, számos olyan technológiai változás történt, amely megkönnyíti a kompozit mutatók létrehozását. Nemcsak önmagában az adatbőség és az adatok 
könnyebb elérhetősége, mint adatoldali előfeltétel adott, hanem a számítógépek terjedésével ma már néhány gombnyomással lehet új és új kompozit indikátorokat számítani. A papír, ceruza és számológépek világában ez még napok kérdése lett volna, vagy csak elméletileg lehetséges, gyakorlatilag lehetetlen feladat többezer megfigyelési egység és többszáz indikátor mellett. Manapság a számítási rész gyakorlatilag elhanyagolható időigényt képvisel a teljes elemzési folyamatban, amennyiben az adatok megfelelően elő vannak készítve.

Végül, ötödik pontként meg lehet említeni a kvantifikáció terjedésének általános megatrendjét. Óriási erőforrások, rengeteg idő megy el a társadalmi kvantifikációra, a különböző jelenségek rangsorolására és pontszámozására: éttermek, szállodák, filmek, könyvek, zeneszámok, látnivalók, oktatók, orvosok, egyetemek, kórházak és sokminden más képezi tárgyát ennek a folyamatnak, amelynek vannak pozitív hatásai és óriási veszélyei is (Power 1997, O’Neil 2015, Espeland-Sauder 2016, Merry 2016, Muller 2018, Mau 2019).

\section{Az okos városok kompozit mutatói és inadekvát alapindikátorai}

Az indirekt változók használatával kapcsolatos egyik veszély az, hogy a koncepció leírására használt változóknak valamilyen okból semmi köze nem lesz a koncepcióhoz. Ez olyan koncepcióknál, amelyeknek még egységes meghatározása sincs, szinte természetes, vagy nem is ellenőrizhető. Az okos város fogalom ilyen bizonytalan jelentésủ fogalom, amit bizonyít sokféle meghatározása és a meghatározásokat bemutató, elemző tanulmányok léte is (utóbbira példa Albino et al. (2015) és Mora et al. (2017) tanulmánya). Az okos városok mérésére számos kompozit indikátort javasoltak és alkalmaztak (néhány példa Giffinger et al. 2007, Zygiaris 2013, Lazaroiu-Roscia 2012, Lombardi et al. 2012, Carli et al. 2013, Nagy et al. 2018). Ezek mind valamilyen alapindikátoroknak a kombinációiból állnak össze. A felhasznált indikátorokban vannak átfedések, de teljes azonosság két okból sincs. Egyrészt, más időpontra és más városok körére eltérő az elérhető adatok köre. Másrészt egy már korábban kidolgozott index számítását megismételni nem tekintenek olyan nagy tudományos érdemnek, mint egy saját javaslat révén számítottat (ami, mint azt korábban írtam, teljes ellentéte a standardizált és ezért összehasonlítható tesztekre törekvő pszichometriai gyakorlatnak). A tanulmányok többnyire úgy indokolják a kiválasztott indikátorok körét, hogy megnézték a vonatkozó szakirodalmat, fókuszcsoportos megbeszélést tartottak és kompromisszumokat is kellett kötni, mivel a meglévő, elérhető adatokból kellett dolgozniuk. Gyakori a részindexek számítása, amit a felhasznált alapindikátorok nagy száma lehetővé tesz. A részindexekre vonatkozóan a gazdaság, közlekedés, életkörülmények, emberek, kormányzás, környezet és hasonló kategóriákat találunk, de mivel mindegyik felmérés eltérő konkrét mutatószámokat használ, ezért megtévesztő lenne azt gondolni, hogy ezek teljesen ugyanazt is jelentik a különbözö elemzésekben. A meglepő és különös azonban az, hogy az indikátorok többségének semmi köze nincs a digitalizációhoz, információtechnológiához, hanem egyszerüen vagy hagyományos mutatókról van szó, vagy valamilyen újabb, de a digitalizációval nem kapcsolatos jelzőszámról. 
Öt kompozit okos város mutató alapján fogok olyan példákat bemutatni, amelyekkel szemben kivétel nélkül felhozható az a kifogás, hogy azok hagyományos mutatók, amelyeknek nincs közük a digitalizációhoz. Ezen túlmenően azonban további módszertani nehézségek is jellemzők lesznek rájuk, amely nehézségeket bemutatásuk elött röviden a következőkben sorolom fel:

1. A mutató nem létezik (nem mérhető, nem értelmezhetö) településszinten, csak országos szinten vagy régió szinten.

2. A mutató eltérő településnagyságoknál egészen mást jelent vagy eltérő módon operacionalizálható.

3. Abszolút (nem fajlagos) mutatók, amelyek nagysága függ a településmérettől.

4. Előző évhez viszonyított változást kifejező mutatók, amelyeknek a nagysága attól függ, mekkora volt a bázisérték (ez ritkán, de azért előforduló koncepcionális hiba).

5. Koncepciójában is problémás, mert nem világos, hogy jelenlétük, kicsi vagy nagy voltuk mit jelent, előnyös-e vagy hátrányos-, vagy nagyságuk egyáltalán értelmezhető-e egy pozitív-negatív skálán.

Az első és második példa mögött zárójelben látható számok a fenti pontokban megfogalmazott problémák jelenlétére utalnak az adott jellemzőnél. Ahol nincs ilyen szám, ott egyéb problémák vannak: tartalmi kapcsolat hiánya az okossággal, definíciós nehézségek, területközi és időbeli összehasonlítási nehézségek és/vagy megfigyelhetőségi problémák. Az első ilyen, illusztratív célokra felhasznált smart city indexet a Navarrai Egyetem publikálja évente Cities in motion név alatt 2014 óta, évről évre kicsit változó világvárosok körére (2018-ban 165 világvárosra) és alapindikátorkészletet felhasználva (2018-ban 77 alapindikátorral) (IESE, 2018). A gazdasági alindex alapindikátorai között találjuk a következőket:

- munkaproduktivitás, GDP/foglalkoztatottak száma (forrás: Euromonitor) $(1,2)$

- az üzletindításhoz szükséges naptári napok száma (Világbank) (1)

- $\quad$ szabályozási környezet (Világbank) (1)

- $\quad$ éves GDP növekedés (Euromonitor) $(1,2,4)$

- $\operatorname{GDP}$ (Euromonitor) $(1,2,3)$

- $\mathrm{GDP} /$ fö (Euromonitor) $(1,2)$

Ezek hagyományos gazdasági mutatók. Forrásukat azért jelöltem meg, mert érzékeltetik, hogy az indikátorok szinte sohasem egyéni adatgyüjtésből származnak, hanem más intézményektől átvettek. A fentieknek a mérési szintje nem a település, hanem az ország, jobb esetben régió. Szerepel közöttük településnagyságtól függő (a GDP nagysága) és fajlagos mutató is (GDP/fö). A Cities in motion nevü smart city mutatónak néhány további, az okosság szempontjából tartalmilag nagyon furcsa indikátora:

- átlagos lakásbérleti díjak $(2,5)$

- múzeumok száma (3)

- müvészeti galériák száma (3)

- $\quad$ szén-dioxid kibocsátás (1)

- jövőbeli klíma (1) 
- metróállomások száma $(2,3)$

- benzinkutak száma (3)

- McDonalds éttermek száma (3)

- felhőkarcolók száma (3)

- szegénységi index (1)

- női foglalkoztatottak aránya a közszférában (5)

- népsürüség (5)

- etnikai sokszínúség (5)

- béke index (1).

Egy másik, gyakran hivatkozott okos város indexet a Bécsi Müszaki Egyetem publikálja, a projekt számára létrehozva a http://www.smart-cities.eu/ honlapot, amely így nagyobb láthatóságot és hivatkozottságot biztosít számukra. Eddig négy jelentésük jelent meg (az okos városok négy „modellje” a saját megfogalmazásukban), 2007, 2013 és 2014 a 100 és 500 ezer fö közötti európai uniós városokat (a 2014-es jelentés 77 várost vizsgált, a magyar városok közül Györ, Miskolc és Pécs szerepelt), a 2015-ös jelentés a 300 ezer és 1 millió fö közötti városok közül 90-re, 21 országból. A 2007-es vizsgálat 2001 és 2007 közötti időszakra vonatkozó (indikátoronként eltérőek az évek) 74 indikátort használt, amelyből 35 volt település szintü, 13 regionális, 26 országos, köztük a következőkkel (Giffinger et al. 2007):

- egyéni vállalkozók aránya (1)

- szabadalmi bejelentések száma ezer lakosra

- munkanélküliségi ráta (1)

- légiutasok száma (2)

- légi áruforgalom volumene (2)

- egy lakosra jutó kölcsönzött könyvek száma

- külföldiek aránya (5)

- külföldön született állampolgárok aránya (5)

- szavazók részvételi aránya az európai választásokon

- az Európai Unióval kapcsolatos ismeretek szintje (1)

- gyilkossági ráta (2)

- születéskor várható élettartam (1)

- mozi látogatottság lakosonként

- múzeum látogatottság lakosonként (2)

- turista vendégéjszakák száma ezer lakosra (2)

- nyelvtanfolyamokon részvétel (1)

- szegénységi ráta (1)

- napsütéses órák száma.

A harmadik kompozit mutató, amelyből példákat válogatok, az Európai Digitális Város Index (European Digital City Index, https://digitalcityindex.eu, Bannerjee et al. 2016). Ez annyiban eltérö a többitöl, hogy nagyobb az aránya a digitalizációra vonatkozó adatoknak, amelyek minősége, naprakészsége ugyanakkor jellemzően a leggyengébbek közé tartozik. Az egyéb indikátorok azonban itt is 
eltérítik a digitalizációtól a kompozit mutató súlypontját. Némelyik furcsa indikátornál megjelöltem forrásukat:

- újonnan regisztrált vállalkozások aránya (Világbank, országos)

- üzleti angyalok által történő finanszírozás nagysága (Európai Üzleti Angyalok Hálózat adata)

- közösségi finanszírozás modellel gyüjtött összeg

- a vállalkozásokkal kapcsolatos adminisztrációhoz szükséges idő és költség (Világbank, országos)

- azoknak az embereknek az aránya, akik nem értettek egyet azzal az állítással, hogy ,,az embereknek nem érdemes vállalkozást indítani, mert lehet, hogy nem sikerül'" (ez az Eurobarometer 2013-as felmérés kérdése volt, NUTS2 szintü adat)

- azoknak az aránya, akik pozitívan válaszoltak arra a kérdésre, hogy „mi a véleménye a vállalkozókról?" (Eurobarometer 2013)

- válasz arra a kérdésre, hogy a legtöbb ember megbízható-e (Eurobarometer 2013)

- angolul kommunikálni tudó lakosság aránya

- TOP 200 kutatóintézet száma (QS egyetemi rangsor)

- a külföldön született lakosság aránya

- 3 órán belül vasúttal elérhető lakosság száma

- kulturális létesítmények átlagos minőségi pontszámai

- felsőfokú végzettségüek aránya a 25-64 éves korosztályban

- online vásárlók számának növekedése 2013 és 2014 között (\%)

- a munkába utazás átlagos ideje

- a helyi reptérről induló járatok száma.

Sikora-Fernandez 16 lengyel nagyvárost hasonlított össze 41 alapindikátorral, többek között ezekkel:

- innovatív vállalkozások aránya

- új cégek száma 10000 lakosra

- népsürüség

- $\quad$ egy före jutó zöldfelület nagysága

- idegennyelv-tudás

- $\quad$ szelektíven gyüjtött hulladék aránya

- megújuló energiatermelés aránya

- közösségi kerékpárok száma 10000 lakosra

- kerékpárutak hossza 10000 lakosra

- külföldiek aránya az egyetemeken

- mozi ülőhelyek száma 10000 lakosra

- büntények 10000 lakosra

- egy före jutó EU támogatás

- közlekedési balesetben meghaltak száma 100 ezer lakosra

- nők aránya a városi közgyülésben. 
Végül egy indiai okos város index (az 53 egymillió főnél nagyobb indiai városra) néhány indikátorát mutatom be, amelyből érzékelni lehet a földrajzi eltérések jelentőségét (ISB 2017):

- hozzáférés az elektromos áramhoz

- elektromos áramszolgáltatás minősége

- hozzáférés az vízszolgáltatáshoz

- egy före jutó vízszolgáltatás

- tüzvészben meghaltak száma 100000 lakosra

- gyerekhalandóság

- nyomornegyedekben élők aránya

- hajléktalanok aránya

- hulladékgyüjtés elérhetősége

- múzeumok száma 100000 lakosra

- regisztrált jármúvek száma 100000 lakosra.

A példák sokáig folytathatók lennének. A fenti esetek rámutatnak arra, hogy nagyon sokféle súlyos problémával lehetnek terheltek ezek az indexek. Az adathiányt meg sem említettem; az indiai példánál van olyan indikátor amely az 53 településből csak 18-nál volt elérhető. Ezek a problémák el vannak zárva mindazok elől, akik csak a végeredményt nézik meg, magukat az alapindikátorokat nem. A legellentmondásosabbak azok a mutatók, amelyeknél nem dönthető el, hogy nagy vagy kicsi voltuk-e az előnyös, pozitív, „okos”: népsürüség, útsürüség, lakásbérleti díjak, etnikai sokszínüség, külföldön született lakosság aránya - utóbbi mutatók megítélése ideológiát tükröz, nem egy térség okosságát.

\section{Következtetések}

Röviden levonva a következtetéseket, nem vitatható a kompozit indikátorok nagyon értékes információkkal szolgálhatnak, ha a vizsgált jelenséget jól leíró alapmutatókra vonatkozó primer adatgyüjtés társul hozzájuk, de még ekkor is értelmezési, felhasználási korlátot jelenthet a nehezen megfogható voltuk. Ha azonban a koncepció maga kérdéses, nem jól meghatározott, a kompozit indikátor képzéséhez felhasznált alapadatok pedig nem adekvátak, mint az a bemutatott okos város mutatóknál tapasztalható, akkor az eredmények megtévesztőek lesznek, különösen, ha csak a kompozit mutatók megnevezésére használt hangzatos címkéket ismeri a felhasználó, és nincs tudomása az indikátor képzéséhez felhasznált vitatható alapmutatókról.

\section{Köszönetnyilvánítás}

A tanulmány a "Nemzetköziesítés, oktatói, kutatói és hallgatói utánpótlás megteremtése, a tudás és technológiai transzfer fejlesztése, mint az intelligens szakosodás eszközei a Széchenyi István Egyetemen” elnevezésü, EFOP-3.6.1-162016-00017 azonosítóval ellátott projekt keretében készült. 


\section{Felhasznált irodalom}

Albino, V.- Berardi, U. - Dangelico, R. M. (2015): Smart Cities: Definitions, Dimensions, Performance, and Initiatives. Journal of Urban Technology, 22, 1, 3-21.

Bannerjee, S. - Bone, J. - Finger, Y. (2016): European Digital City Index Methodology Report. Nesta Report.

Carli, R. - Dotoli, M. - Pellegrino, R. - Ranieri, L. (2013): Measuring and Managing the Smartness of Cities: A Framework for Classifying Performance Indicators. Proceedings of IEEE Systems. Man, and Cybernetics, 1288-1293.

Espeland, W. N. - Sauder, M. (2016): Engines of Anxiety: Academic Rankings, Reputation, and Accountability. Russell Sage Foundation, New York.

Feenan, R. - Kelly, J. - McBryde, W. - Clark, G. - Moonen, T. (2017): Decoding City Performance: The Universe of City Indices. Jones Lang Lassale, Chicago, London, Singapore.

Giffinger, R. - Fertner, C. - Kramar, H. - Kalasek, R. - Pichler-Milanovic, N. Meijers, E. (2007): Smart Cities: Ranking of European medium-sized cities. Vienna University of Technology, Vienna.

ISB (Indian School of Business) (2017): Smart Cities Index. A tool for evaluating cities. ISB Punj Lloyd Institute of Infasructure Management, Mohali.

IESE Cities in Motion Index (2018): Business School University of Navarra. DOI: https://dx.doi.org/10.15581/018.ST-471

Korpás, A. (1996): Általános statisztika I. Nemzeti Tankönyvkiadó, Budapest.

Lazaroiu, G. C. - Roscia, M. (2012): Definition Methodology for the Smart Cities Model. Energy, 47, 1, 326-332.

Lombardi, P. - Giordano, S. - Farouh, H. - Yousef, W. (2012): Modelling the Smart City Performance. Innovation: The European Journal of Social Science Research, 25, 2, 137-149.

Mau, S. (2019): The Metric Society. On the Quantification of the Social. Polity Press, Cambridge

Merry, S. E. (2016): The Seduction of Quantification. Measuring Human Rigths, Gender Violence, and Sex Trafficking. University of Chicago Press, Chicago.

Mora, L. - Bolici, R. - Deakin, M. (2017): The first two decades of smart-city research: a bibliometric analysis. Journal of Urban Technology, 24, 1, 2-27.

Muller, J. Z. (2018): The Tyranny of Metrics. Princeton University Press, Princeton.

Nagy, Z. - Sebestyénné Szép T. - Szendi D. (2018): Smart cityk teljesítménye a visegrádi országokban. Erdélyi Társadalom, 16, 1, 59-82.

O’Neil, K. (2015): Weapons of Math Destruction. Penguin Books, London.

Power, M. (1997): The Audit Society. Rituals of Verification. Oxford University Press, Oxford.

Sikora-Fernandez, D. (2018): Smarter cities in post-socialist country: Example of Poland. Cities, 78, 52-59.

UNDP (2018): Human Development Indices and Indicators 2018 Statistical Update. UNDP, New York.

Zygiaris, S. (2013): Smart City Reference Model: Assisting Planners to Conceptualize the Building of Smart City Innovation Ecosystems. Journal of the Knowledge Economy, 4, 2, 217-231. 